\title{
THE BASICS OF EDUCATION FOR ENVIRONMENTALLY RESPONSIBLE BEHAVIOUR
}

\begin{abstract}
Among the various global problems, environmental protection issues have come to the fore. Problems related to this area frequently call for being considered within the process of education. Recurrent conferences, bringing together experts from various fields of science, politicians, and even activists, clearly illustrate the fact that the issue of environmental protection is invariably topical, and should thus be permanently present in the mind of the average person. The environment is an area of manifold human activities, and it requires taking appropriate protective measures. Moreover, its specific elements are linked in close relationships and interdependencies. Therefore, the question whether raising awareness, which is so strongly reliant on education, shapes appropriate attitudes, allowing individuals to act in the social and natural environment, seems to be of much relevance, today. A group of various values compels us to show and promote the importance of ecological values, including the value of responsibility. Those values provide the basis and measure of the change in human attitude towards the social and natural environment, which unfortunately, has taken a one-dimensional form, namely, that of exploiting nature's resources.

The article presents the justification for taking into account proposals of environmental ethics in the educational process. It seems that they can provide the basis for shaping responsible human behaviour, expressed, among others, in mature awareness of the need to protect the environment.
\end{abstract}

Keywords: education; environmental education; environmental ethics; responsibility.

\footnotetext{
* Dr Marcin Klimski, Cardinal Stefan Wyszyński University in Warsaw, Institute of Pedagogy, e-mail:m.klimski@uksw.edu.pl.
} 


\section{Introduction}

The second half of the 2oth century brought mankind a global reflection on the state of the socio-natural environment, and in particular of its individual components. This reflection originated from numerous international events. Among others, it can be traced back to the 1972 report, titled: The Limits to Growth compiled by the Club of Rome members. The report provided data-supported information, which showed that growth in the socio-economic field cannot be indefinite. Its limits are defined by intensely depleting natural resources which humanity vigorously uses, thus potentially leading to an ecological disaster (Klimska, Klimski 2009). Following the report, other studies conducted on specific elements of the environment, such as the atmosphere, lithosphere, hydrosphere, cosmosphere with the magnetosphere, biosphere and anthroposphere, also forced ethical reflection on the unfavourable changes that they are undergoing (Dołęga 2005). Consequently, there arose a need to include environmental protection issues in the educational process, carried out at all stages of formal and non-formal education. Knowledge related to the area of environmental protection is subject to changes caused by different dynamics, which makes its continuous updating a necessity, which in turn is in line with the mission of the Lifelong Learning strategy. Comprehensive Lifelong Learning education, including its formal, non-formal, and informal forms, is defined as: "learning outcomes divided into knowledge, skills and competences" (Kaniewska, Klimski 2014). It can, therefore, be concluded that "the need for permanent education arises from the conditions of the contemporary, constantly changing socio-cultural reality to which each individual must adapt, and which he or she must understand" (Wroczyński 2003, p. 903).

\section{Environmental education}

While considering the issues related to the promotion and use of the postulates of environmental ethics in environmental education, it is necessary to indicate what it is and why educational activities are undertaken. Discussions on eco-education must highlight that such education is a process shaping human preferred behaviours towards the environment, and that it takes place on the psychological and pedagogical level, as its main factor is education, pointing to appropriate norms and attitudes (Kozłowska 1997). All attitudes and behaviours that a person manifests are acquired or become a consequence of the external environment. Both the former and the latter should be attributed to the factors contributing to a person's education and influencing the dimension of this education. Both education in a general sense and education focusing on environmental issues, can take place at various levels, and it can involve the use of numerous methods or ways of implementation. Therefore, during the realisation of educational activities, the key role will be played by all entities that undertake realisation of environmental education guidelines 
implemented in the Lifelong Learning perspective. The main goals defined for implementation, as part of the eco-education process, hark back to the resolutions of the international conference in Tbilisi in 1977. The "Tbilisi Declaration" was the conference's outcome that focused on structural matters, forms of environmental education, and the validity of its implementation at individual stages of education (Hull 1993). Important postulates which provided guidelines for works on environmental education, included:

- universal public access to knowledge about the state of the environment and its changes;

- dissemination of all environmentally friendly behaviours and attitudes, including environmental protection;

- sensitising individuals to factors having a destructive influence on the balance of the biosphere;

- creating ecological culture through references to axiology in environmental protection;

- undertaking and promoting activities aimed at unifying international efforts for the sake of the environment (Bohdanowicz, 2005).

Achievement of the above goals in the process of education may certainly contribute to developing pro-environmental social attitudes imperative for the process of educating individuals responsible for the condition of the natural environment.

\section{Environmental education and its implementation levels}

Adoption of guidelines formulated for the psychological and educational process in the context of environmental education can take place on three levels. The first is education provided within a formal organisational framework. It embraces a formalised system of knowledge transfer. Recipients of this form of education include children, adolescents, and adults, since educational content dealing with environmental protection issues, is presented in kindergartens, primary schools, high schools, technical schools, universities, open universities or universities of a third age. It also includes all those people who promote pro-environmental attitudes and are interested in raising their qualifications. The forms of activity focusing on ecological issues are included in the core curricula adapted to particular stages of education.

The non-formal level is the second form of providing education for environmental protection. The methods used within this type of education include the means of individual and group transfer of knowledge. It is provided, among others, through the mass media, social media, non-governmental organisations, cultural centres, national parks, or the recently highly popular Nature and Forest Education Centres (Tuszyńska, Klimski 2021). The third level which is conducive to the implementation of environmental education is the so-called informal (incidental) learning. This form of education is characterised by a casual manner of acquiring knowledge of 
environmental issues, in other words, knowledge transfer happens incidentally, and it is not planned. Assumptions and ideas, together with an axiological reference, which are included in environmental ethics, should be implemented through the above-mentioned forms of education. This applies to the whole society constituted by all social groups. In addition to theoretical transfer of knowledge, direct contact with the natural environment is another effective element of environmental education (Tuszyńska, Klimski 2021). The essence of showing concern for nature plays a key role when it is presented to the youngest generations. This should be taken into account because the process of environmental education is complex and dynamic due to the emerging environmental threats.

\section{The role of environmental ethics in strengthening the education process}

In view of the above-mentioned findings, environmental ethics, of which, the most effective theoretical and practical prevention of the negative effects of civilisation's progress is the prime postulate, is included in the process of environmental education. Continuous improvement of axiological and deontological guidelines focusing on the desired interdependence between man and the natural environment results in the emergence of a universal model of proper co-existence. Environmental ethics provides appropriate values and norms of behaviour of each individual, which can have positive effects in society. Therefore, environmental ethics supports the education process to a certain degree, focused on the issues of protecting and managing natural resources. Environmental ethics is presented as an educational tool. The theoretical function of environmental ethics is helpful since it translates into practical activities undertaken by both adults and youth belonging to the social and natural environment. The process of ecological education is aimed at promoting the so-called "ecological thinking" in every person. Such an attitude is characterised by actions aimed at developing people's correct attitude to their place of living, i.e., to their environment. They propagate an idea that people should not be separated from nature or its governing laws, because they constitute one of its inseparable links. In addition, ecological thinking is also related to prudent use of environmental resources, based on respecting the laws governing nature. Since ecology considers issues related to the place of a given species' existence, then the issue of maintaining the balance and general order of the socio-natural environment in which people may realise themselves, becomes a matter of importance. Postulates advocating ecological thinking, also include an issue related to the attitude of human domination over the natural world. Its categorical character should not be of key importance, only because, in the common understanding, the world was created and given to man. When relating ecological thinking to the issue of environmental education and environmental ethics, it should be noted that it is one of the basic activities in the sphere of environmental protection. The role of environmental ethics in the sequence of events constituting environmental education, consists in 
encouraging appropriate attitudes and reactions to the surrounding world. This can be achieved by relying on a set of values and norms regulating our behaviour (Tyburski 1999). A person participating in the educational process supported by arguments of environmental ethics, may reflect in his or her actions, the attitude of a "caring host" towards the social and natural environment.

\section{Levels of education towards responsibility for the social and natural environment}

Effectiveness of the implemented eco-education in all its forms, depends on whether the expressiveness of environmental ethics can be realised on cognitive, emotional-volitional, and behavioural levels of teaching and learning.

The cognitive area oscillates around illustrating and justifying the values of environmental ethics, along with normative references of these values. At this level, argumentation is built on the statement that nature has value in itself. Environmental ethics provides all premises supporting such a position, in one of its concepts called "biocentrism". This concept relies on the question of the intrinsic value of all animate beings oriented towards fulfilling their own inner goals. The assumption that individual beings, together with entire populations that they form, are carriers of their own good and have intrinsic values, implies that they deserve due care, and their good must be protected for their own sake. This provides specific legitimacy for preventive actions, undertaken to counteract the extinction of endangered species or entire populations, while preserving the exclusivity of ecosystems. The anthropocentric concept touching upon the plane of environmental ethics, emphasises the existence of values that are due to man and manifested in human relations with nature. These include life, health, responsibility, solidarity, moderation, harmony, and compassion (Tyburski 1998). In terms of environmental ethics, both life and health are paramount values, and therefore, all human activities should take them into account. When implementing the assumptions resulting from the postulates of environmental ethics in the course of conducted environmental education, it is possible to indicate forms of conduct aimed at nurturing and protecting life and health. By using the tool of environmental ethics, the education process embracing various stages of education, helps to ensure that fundamental values do not become mere slogans. In achieving this goal, it becomes important to make people aware of the relationship between responsibility and other values.

People's responsibility for the area of their residence, and thus, for the natural environment, was one of the topics discussed during the 1992 Earth Summit in Rio de Janeiro. The question of responsibility was emphasised in the "Rio Declaration" - one of the five documents adopted during the conference. The Declaration, which contains 27 principles of future rights and obligations, highlights the scale of responsibility for the natural environment, bringing attention to the impact of environmental conditions on the present and future life on Earth (Kozłowski 
2005). Consisting of many closely inter-related elements, the natural environment becomes an object of responsibility, and at the same time, a common good. The fact of regarding an object as "a common good" leads to a certain consequence, namely, to responsibility. If we use the natural environment, we are also responsible for it. The environment provides a basis on which our lives, one of the key values for which, each person is individually responsible, is realised (Marek-Bieniasz, 200o). All values with their very existence testifying that a given object can be considered a common good, should be properly respected. A natural environment, established by certain values, is a common good. It is a universal good that cannot be approached with indifference. Man, as a direct user and recipient of natural resources, should feel responsible for their quality and condition. However, ecological responsibility includes a certain hierarchy. When one object of responsibility is recognised as more valuable than another, then ecological responsibility for such an object becomes greater. Thus, various components of the natural environment have different values, and the subject makes a subjective assessment as to which object of responsibility is more valuable. It should be borne in mind that, nowadays, the perception of the bio-sphere results, among others, from its being shaped by people, themselves. The bio-sphere becomes an object of human responsibility. Undertaking work on developing your inner self, and then manifesting the correct attitude to other natural organisms, is based on the necessity to develop new axiological priorities and a sense of responsibility for them. Educational activities focused on the protection of the social and natural environment become helpful (Marek-Bieniasz, 200o). Responsibility can also be considered one of the main ethical issues that help approach problems brought about by intensive development of civilisation. Viewed through the prism of responsibility, the relationship between global problems and human activity becomes clear. Reference to the question of responsibility, brings to light moral obligations which constitute an imperative formula for the currently thriving civilisation. A correct understanding of responsibility and interpretation of its guidelines is of high importance, so that it may become a stimulating argument galvanising people into action (Ciążela 2006). It intermediates in postulating a change of a certain tendency revealed in the consumer society, which consists in avoiding responsibility, in order not to complicate the existence in the broadly understood environment. The consequence of such an action is a reduction in quality of life standards, along with the deterioration of the place of living. By following the value of ecological responsibility, people reach for further ethical ecological values, comprising among others: moderation, which translates into the rational use of natural resources, humility, oriented towards the natural world, respect for life, and solidarity of the human world with the world of other natural organisms (Marek-Bieniasz, 200o).

Decision-making processes, taking place at various levels, should always refer to the above values. By such a reference, people become in a way more sensitive towards issues, which, on the one hand seem obvious, but on the other, are not 
always used to protect, or at least, to maintain natural balance. Apart from values comprised by environmental ethics, which is undoubtedly important in the educational process, there are also catalogues of norms, principles, or obligations that a person must take into account when co-existing with the natural environment.

The emotional and volitional sphere places emphasis on stimulating and constituting moral evaluation oriented towards issues concerning the natural world. Its implementation should particularly address the educational aspects of working with children. In this area, the key role is played by the development of skilful observation of the social and natural environment, along with possible ways of counteracting any destructive processes that may take place in it. Encouraging young people through various educational techniques, not to be indifferent to environmental issues, is the main guideline for the emotional and volitional plane of environmental education, using environmental ethics as its tool.

The behavioural level focuses on a practical activity, including all manifestations of activity in the field of remedying environmentally destructive processes. Within this sphere of educational impact, it is postulated that knowledge acquired through education should be implemented in practice. In other words, it is necessary to abandon the sphere of declarative knowledge and to activate the acquired skills in everyday life (Tyburski 1998). Therefore, drawing on the principles of environmental ethics may determine the effectiveness of education conducted with the aim of improving and protecting the social and natural environment (Tyburski 2002). The discrepancy between the above-mentioned levels of environmental protection, and the question of ethics, arises from the fact that the former usually refers to various legal regulations and sanctions, which in a way oblige a person to act in one direction. Ethical protection allows addressing one's own sensitivity, to evaluate a specific action in the light of the system of values adopted by an individual, as well as to sensitise him or her to the good and evil happening in the natural world (Tyburski 2002).

\section{Conclusion}

The issues presented in the article seem to be important for preserving the social and natural environment in the best possible condition. It should be remembered that the necessity to protect the environment is one of the current problems faced by the modern world. Academic and social education of young people is a process that has been going on since the beginning of mankind. Initially, the process was carried out purely in an intuitive manner, but with the passage of time, it took a more targeted form, and began to be supported by experience gained in the course of its development. Taking into account the values, as well as the related norms and obligations, which are brought about by environmental ethics, contributes to achieving order in the relationship between man and the natural world. The axiological impact manifests itself in thinking and, consequently, in stimulating practical 
solutions in the implementation of daily duties. This is the fundamental challenge facing contemporary environmental education, carried out, amongst others, in its formal and non-formal forms. Referring to the system of values in the process of shaping social attitudes helps to build an ecological culture and formulate an appropriate world view oriented towards establishing a harmonious co-existence between the anthroposphere and the bio-sphere. Similarly, to the cognitive plane, in which the system of values plays an important role, the emotional and voluntary sphere focuses on stimulating one's imagination, especially in young people. There is room for work on the constitution of conscience, which is referred to within the humanistic aspect of environmental protection as "ecological conscience" (Dołęga 1999). It is an extremely important issue, as it touches upon the entire aspect related to responsible functioning of people in the social and natural spheres. The environment's state and quality will depend on the choices made by people, based on knowledge they have acquired.

\section{Bibliography}

Bohdanowicz P. (2005). Turystyka a świadomość ekologiczna. Toruń: Wydawnictwo Adam Marszałek.

Ciążela H. (2006). Problemy i dylematy etyki odpowiedzialności globalnej. Warszawa: Wydawnictwo Akademii Pedagogiki Specjalnej.

Dołęga J.M. (1999). Ekologia w teologii i filozofii chrześcijańskiej. W: Wprowadzenie do filozoficznych problemów ekologii. Papuziński A. (red.). Bydgoszcz: Wydawnictwo Uczelniane Wyższej Szkoły Pedagogicznej, s. 133-163.

Dołęga J.M. (2005). Zarys sozologii systemowej. Warszawa: Wydawnictwo Uniwersytetu Kardynała Stefana Wyszyńskiego.

Ganowicz-Bączyk A. (2009). Spór o etykę środowiskowa. Kraków: Wydawnictwo WAM.

Hull Z. (1993). Filozoficzne podstawy edukacji ekologicznej. W: Ochrona środowiska w nauczaniu i wychowaniu. Materiały II Ogólnopolskiej Konferencji Środkowo-Europejskiej. Dudzińska M. R., Pawłowski L. (red.). Lublin: Instytut Badań nad Środowiskiem, s. 509-518.

Kaniewska M., Klimski M. (2014). Kształtowanie świadomości ekologicznej - perspektywa „Lifelong Learning”. „Journal of Modern Science”, nr 3, s. 473-489.

Klimska A., Klimski M. (2009). Edukacja ekologiczna w polskiej szkole. Olecko: Wydawnictwo Wszechnicy Mazurskiej Acta Universitatis Masuriensis.

Kozłowska I. (1997). Edukacja ekologiczna studentów. W: Edukacja i świadomość ekologiczna. Pfeiffer A. (red.). Poznań: Wydawnictwo Akademii Rolniczej, s. $43-57$.

Kozłowski S. (2005). Przyszłość ekorozwoju. Lublin: Wydawnictwo KUL. 
Marek-Bieniasz A. (200o). Istota związku odpowiedzialności ekologicznej z wartościami. W: Polityka, ekologia, kultura. Papuziński A. (red.). Bydgoszcz: Wydawnictwo Uniwersytetu Kazimierza Wielkiego, s. 37-41.

Tuszyńska L., Klimski M. (2021). Edukacja leśna wsparciem zrównoważonego rozwoju społeczeństwa Warszawy. W: Przyroda wyzwaniem dla kultury. Społeczności lokalne wobec obszarów chronionych. Sadowski R.F., Falencka-Jabłońska M. (red.). Sękocin Stary: Instytut Badawczy Leśnictwa, s. 211-220.

Tyburski W. (1998). Etyka środowiskowa - jej kognitywny, wolitywny i behawioralny wymiar edukacyjny. W: Etyka środowiskowa. Teoretyczne i praktyczne implikacje. Tyburski W. (red.). Toruń: Wydawnictwo TOP KURIER, s. 97-103.

Tyburski W. (1999). Główne kierunki i zasady etyki środowiskowej. W: Wprowadzenie do filozoficznych problemów ekologii. Papuziński A. (red.). Bydgoszcz: Wydawnictwo Uczelniane Wyższej Szkoły Pedagogicznej, s. 97-132.

Tyburski W. (2002). Praktyczny wymiar etyki środowiskowej. W: Etyka środowiskowa wyzwaniem XXI wieku. Czartoszewski J.W. (red.). Warszawa: Wydawnictwo Księży Werbistów, s. 105-114.

Wroczyński R. (2003). Kształcenie ustawiczne. W: Encyklopedia pedagogiczna XXI wieku. Pilch T. (red.). Warszawa: Wydawnictwo Żak, s. 903.

\section{PODSTAWY NAUCZANIA I WYCHOWANIA CZŁOWIEKA DO ODPOWIEDZIALNEGO DZIAŁANIA W ŚRODOWISKU}

Streszczenie: Wśród rozmaitych problemów globalnych szereg z nich dotyczy ochrony środowiska. Tak zorientowana problematyka nierzadko domaga się uwzględniania jej $\mathrm{w}$ procesie wychowania wspartego nauczaniem. Cyklicznie organizowane konferencje, zrzeszające ekspertów z różnych dziedzin nauki, polityków, a nawet aktywistów, wskazują, że problematyka ochrony środowiska jest ciągle żywa, a tym samym powinna na stałe zaistnieć w świadomości przeciętnego człowieka. Środowisko jest obszarem rozmaitej aktywności ludzkiej i wymaga odpowiednich działań ochronnych. W nim występują też ścisłe zależności pomiędzy konkretnymi jego elementami. Dlatego wciąż aktualne staje się pytanie, czy wychowanie, które tak mocno wspierane jest przez edukację, kształtuje w człowieku odpowiednie postawy, w oparciu o które można postępować w środowisku społeczno-przyrodniczym? Zbiór rozmaitych wartości wymusza ukazanie i promowanie znaczenia wartości ekologicznych, wśród których znajduje się m.in. wartość odpowiedzialności. Są one podstawą i miarą zmiany stosunku człowieka wobec środowiska społeczno-przyrodniczego, co niestety przyjmuje jednowymiarową postać. Jest nią eksploatacja jego zasobów. W artykule przedstawiona zostanie zasadność uwzględniania w procesie edukacyjnym propozycji, jakie głosi etyka środowiskowa. Wydaje się, że mogą one stanowić podstawę do kształtowania odpowiedzialnych zachowań ludzkich wyrażających się m.in. w dojrzałej świadomości potrzeby ochrony środowiska.

Słowa kluczowe: edukacja, edukacja ekologiczna, etyka środowiskowa, odpowiedzialność. 